\title{
Budaya Organisasi, Lingkungan Kerja, Kompensasi dan Kinerja Karyawan di Koperasi Pasar Srinadi Klungkung
}

\author{
Ni Putu Maetri Megantari ${ }^{1}$ \\ Fakultas Ekonomi dan Bisnis \\ Universitas Udayana, Indonesia
}

\author{
Ida Bagus Putra Astika² \\ Fakultas Ekonomi dan Bisnis \\ Universitas Udayana, Indonesia
}

\begin{abstract}
Surel : maetri.megantari@yahoo.com
\section{ABSTRAK}

Tujuan penelitian ini adalah untuk memperoleh bukti empiris pengaruh budaya organisasi, lingkungan kerja dan kompensasi pada kinerja karyawan di Koperasi Pasar Srinadi Klungkung. Penelitian ini dilakukan di Koperasi Pasar Srinadi Klungkung. Jumlah sampel yang diambil sebanyak 50 karyawan bagian akuntansi dan bagian keuangan, dengan metode non probability sampling dengan teknik purposive sampling. Pengumpulan data dilakukan melalui kuesioner. Teknik analisis yang digunakan adalah regresi linear berganda. Berdasarkan hasil analisis ditemukan bahwa budaya organisasi, lingkungan kerja dan kompensasi berpengaruh positif pada kinerja karyawan. Hal ini menunjukkan bahwa dengan budaya organisasi dan lingkungan yang baik, serta diberikannya kompensasi pada karyawan maka kinerja karyawan akan semakin meningkat. Hasil penelitian ini dapat memberikan tambahan informasi dalam kajian empiris mengenai pengaruh budaya organisasi, lingkungan kerja dan kompensasi pada kinerja kayawan.
\end{abstract}

Kata Kunci: Budaya Organisasi; Lingkungan Kerja; Kompensasi; Kinerja Karyawan.

\section{Organizational Culture, Work Environment, Compensation and Employee Performance at Pasar Srinadi Klungkung Cooperative}

\begin{abstract}
The purpose of this study was to obtain empirical evidence of the influence of organizational culture, work environment and compensation on employee performance at the Srinadi Klungkung Market Cooperative. This research was conducted at the Srinadi Klungkung Market Cooperative. The number of samples taken as many as 50 employees accounting and finance section, with non probability sampling method with purposive sampling technique. Data collection is done through a questionnaire. The analysis technique used is multiple linear regression. Based on the results of the analysis it was found that organizational culture, work environment and compensation had a positive effect on employee performance. This shows that with a good organizational culture and environment, and giving compensation to employees, employee performance will increase. The results of this study can provide additional information in empirical studies regarding the influence of organizational culture, work environment and compensation on employee performance.
\end{abstract}

Keywords: Organizational Culture; Work Environment; Compensation; Employee Performance.

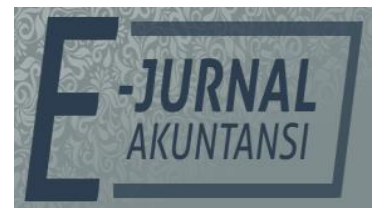

e-ISSN 2302-8556

Vol. 31 No. 5

Denpasar, Mei 2021

Hal. 1110-1124

DOI:

10.24843/EJA.2021.v31.i05.p04

PENGUTIPAN:

Megantari, N.P.M., \& Astika, I.B.P. (2021). Budaya Organisasi, Lingkungan Kerja, Kompensasi dan Kinerja Karyawan di Koperasi Pasar Srinadi Klungkung. E-Jurnal Akuntansi, 31(5), 1110-1124

RIWAYAT ARTIKEL: Artikel Masuk: 29 Maret 2019 Artikel Diterima: 25 Mei 2021

Artikel dapat diakses : https://ojs.unud.ac.id/index.php/Akuntansi/index 


\section{PENDAHULUAN}

Peraturan Menteri Koperasi dan Usaha Kecil dan Menengah Nomor 20 Tahun 2015 mengatur tentang Penerapan Akuntabilitas Koperasi menyebutkan bahwa akuntabilitas merupakan perwujudan kewajiban suatu entitas untuk mempertanggungjawabkan keberhasilan dan kegagalan pelaksanaan misi organisasi dalam mencapai tujuan-tujuan dan target-target yang telah ditetapkan. Laporan akuntabilitas koperasi berbentuk laporan keuangan yang wajib dipertanggungjawabkan oleh pengurus atau pengelola koperasi secara periodik biasanya setiap tahun. Pengurus harus responsif terhadap regulasi seperti halnya Peraturan Menteri Koperasi dan Usaha Kecil dan Menengah Nomor 20 Tahun 2015. Respon menyangkut tentang kesesuaian pelaksanaan dengan peraturan perundang-undangan yang berlaku dan prinsip-prinsip pengelolaan manejemen yang sehat. Dalam manajemen yang sehat terdapat transparansi yang merupakan bentuk keterbukaan dalam proses pengambilan keputusan maupun keterbukaan dalam mengemukakan informasi yang materiil dan relevan tentang operasional koperasi.

Koperasi merupakan bentuk usaha yang memiliki peran membangun perekonomian Indonesia diluar sektor pemerintah dan sektor swasta. Koperasi adalah salah satu pendorong pertumbuhan ekonomi yang berbasis ekonomi kerakyatan. Undang Undang No. 25 tahun 1992 menyebutkan bahwa koperasi merupakan badan usaha yang beranggotakan oleh seseorang atau badan hukum koperasi dengan melandaskan prinsip-prinsip koperasi sekaligus sebagai gerakan ekonomi kerakyatan yang berlandaskan atas azas kekeluargaan.

Menurut Ropke dan diterjemahkan Djatnika (2003) mengungkapkan bahwa koperasi yang didasarkan atas azas kekeluargaan dan bersifat umum, sukarela, dan terbuka yang bertujuan untuk meningkatkan perekonomian sekaligus mewujudkan masyarakat yang maju.

Undang Undang No. 25 Bab II Pasal 3 Tahun 1992 mendeskripsikan bahwa, "Koperasi bertujuan memajukan kesejahteraan anggota pada khususnya dan masyarakat pada umumnya serta ikut membangun tatanan perekonomian nasional dalam rangka mewujudkan masyarakat maju, adil dan makmur berdasarkan Pancasila dan Undang-Undang Dasar 1945". Sesuai dengan bunyi Pasal 3, maka tujuan utama koperasi adalah memajukan kesejahteraan anggotanya dan jika nantinya telah mampu, dapat memperluas usaha ke masyarakat disekitar, sehingga dengan cara ini diharapkan koperasi dapat berperan serta dalam meningkatkan taraf hidup masyarakat. Menurut Sitio, Arifin (2011) koperasi mempunyai peranan di Indonesia, yaitu sebagai alat perjuangan ekonomi untuk mempertinggi kesejahteraan rakyat, sebagai alat pendemokrasian ekonomi nasional, sebagai salah satu urat nadi perekonomian bangsa.

Koperasi akan lebih berdaya saing jika koperasi mampu membentuk jaringan usaha, karena melalui jaringan yang kuat, koperasi akan mampu berkiprah di pasar global melalui peningkatan mutu pelayanan (Kanaidi, 2015). Koperasi memiliki dua kelompok aset yaitu sumber daya ekonomi dan sumber daya manusia. Sumber daya manusia memiliki peran untuk mengelola sumber daya ekonomi yang dimiliki. Sebagai konsekuensinya organisasi memerlukan sumber daya manusia (SDM) yang memiliki kompetensi yang memadai untuk 
dapat bersaing. Kemampuan bersaing perusahaan melalui SDM berarti meletakkan peran orang untuk selalu melakukan peningkatan kualitas dan inovasi baik terhadap proses, sistem maupun produk. Melalui cara ini, koperasi diharapkan bisa mempertahankan, meningkatkan market share, atau memperluas pasar dibandingkan dengan kekuatan pesaing dalam industri (Alwi, 2001:34).

I Dewa Nyoman Patra, S.H., M.H., Kepala Dinas Koperasi dan UKM Provinsi Bali 2017 menyatakan bahwa dari total 4.989 koperasi yang ada di Pulau Dewata sebanyak $10 \%$ dinilai tidak aktif. Namun walaupun sebanyak $10 \%$ koperasi dinilai tidak aktif, pembubaran koperasi-koperasi tersebut belum dilakukan. Koperasi-koperasi ini masih diberi kesempatan untuk melakukan kembali Rapat Anggota Tahunan (RAT) sehingga dapat beroperasi lagi. Jumlah koperasi di Kabupaten Klungkung tahun 2017 tercatat sebanyak 136 koperasi, dengan jumlah koperasi tidak aktif sebanyak 28 koperasi. Tujuan gerakan melaksanakan RAT, menurut Erwin Suryadarma selaku Kepala Dinas Koperasi UMKM Denpasar yaitu untuk mempertanggungjawabkan pengelolaan koperasi kepada anggotanya (www.kabar24.bisnis.com).

Koperasi Pasar Srinadi Klungkung (Koppas Srinadi) merupakan salah satu koperasi yang perkembangannya tergolong sangat cepat. Saat ini, Koppas Srinadi Klungkung merupakan koperasi terbesar di Kabupaten Klungkung. Pemilihan lokasi yang strategis dan dukungan manajemen maupun karyawan menjadikan koperasi mampu memberikan kontribusi dalam pertumbuhan ekonomi yang berbasis ekonomi kerakyatan di Kabupaten Klungkung. Pada tahun 2018 tercatat Koppas Srinadi telah memiliki 12.651 anggota. Koppas Srinadi juga berprestasi di tingkat Kabupaten, Provinsi, dan Nasional, dengan mengembangkan sembilan unit usaha yaitu unit Simpan Pinjam, Grosir, Swalayan Mini, Percetakan dan Konveksi, Swalayan Rama Bangunan, Supermaket Inti, Wisata Tirta Srinadi, Bengkel Srinadi, dan Radio Srinadi 99,7 FM. Pengembangan unit usaha tersebut diharapkan dapat menyentuh kebutuhan anggota maupun masyarakat dan akan berpengaruh pula pada kesejahteraan anggota maupun masyarakat sesuai dengan tujuan koperasi tersebut.

Pencapaian Koppas Srinadi tidak lepas dari peran karyawan selaku sumber daya manusia yang mengelola sumber daya ekonomi, khususnya karyawan-karyawati dibagian operasional. Sampai saat ini Koppas Srinadi memiliki 304 orang karyawan dari sembilan unit usaha yang ada. Kinerja karyawan pada sebuah koperasi merupakan pilar untuk menjalankan siklus hidup koperasi, dimana para karyawan ditempatkan, dan kinerja karyawan akan terlihat seiring dengan hasil yang diperoleh dalam jangka waktu tertentu.

Salah satu faktor yang mempengaruhi kinerja karyawan di Koppas Srinadi adalah kompensasi. Pemberian kompensasi dapat dilihat sebagai sebuah strategi manajemen sumber daya manusia untuk mempertahankan dan memotivasi para karyawan untuk tetap berkomitmen terhadap organisasi. Kompensasi tidak hanya berfungsi sebagai balas jasa, tetapi kompensasi dapat memotivasi karyawan agar tetap berada dalam organisasi sehingga dapat diajak bekerjasama untuk memajukan organisasi. Pemberian kompensasi yang sesuai dengan prosedur akan menumbuhkan rasa memiliki terhadap organisasi, yang akan berdampak pada meningkatnya komitmen pada organisasi (Retnaningsih, 2007). 
Stewardship theory mengemukakan bahwa karyawan akan bekerja dengan penuh tanggung jawab untuk mencapai kepentingan organisasi. Kebijakan koperasi untuk memberikan kompensasi berupa tunjangan kerja dan pemberian penghargaan dapat memotivasi karyawan untuk meningkatkan kinerjanya. Beberapa penelitian tentang pengaruh kompensasi pada kinerja yang telah dilakukan menunjukkan hasil yang berbeda-beda. Seperti penelitian yang dilakukan oleh Supianto (2015), Nurcahyani \& Adnyani (2016), Muhammad dan Abdullah (2016) menemukan bahwa kompensasi memiliki pengaruh positif pada kinerja. Kemudian terdapat pula penelitian dengan hasil yang menunjukkan bahwa kompensasi berpengaruh negatif pada kinerja seperti penelitian yang dilakukan oleh Vertasari \& Zunaidah (2014).

Faktor lain yang diduga mempengaruhi kinerja karyawan adalah budaya organisasi. Budaya organisasi merupakan suatu hal yang penting untuk dimiliki oleh organisasi, khususnya bagi pelayanan publik sebagai salah satu alat dalam mewujudkan sasaran dan target yang telah ditentukan. Dengan adanya budaya kerja yang baik dalam organisasi, pikiran atau ide seluruh kinerja karyawan dapat disamakan dan disatukan dalam suatu visi dan misi yang kemudian memunculkan suatu aktivitas yang bermanfaat dalam mengembangkan dan memajukan dalam pelayanan. Penelitian sebelumnya tentang budaya organisasi juga telah banyak dilakukan dengan hasil yang berbeda. Penelitian oleh Ponnu \& Hassan (2015), Evawati \& Suharno (2015), Usmany et al. (2016) menyatakan bahwa budaya organisasi berpengaruh signifikan terhadap kinerja karyawan. Penelitian oleh Syauta et al. (2012) menyatakan bahwa budaya organisasi tidak berpengaruh secara langsung terhadap kinerja pegawai dan penelitian Trisnaningsih (2007) memperoleh hasil budaya organisasi tidak berpengaruh langsung terhadap kinerja auditor. Penelitian yang dilakukan oleh Kim et al.(2004), Tseng (2010), dan Oparanma (2010) berkaitan dengan pengaruh budaya organisasi terhadap kinerja memiliki ruang lingkup luas akan tetapi hasilnya tidak meyakinkan karena adanya perbedaan dan masalah definisi, struktur, dan desain.

Kinerja karyawan juga dapat dipengaruhi oleh faktor lingkungan kerja. Lingkungan kerja merupakan hal penting yang dapat berimplikasi dalam meningkatkan kinerja (Olson \& Borman, 1989). Lingkungan kerja yang kondusif baik kondisi fisik maupun non fisik, akan mendorong untuk melaksanakan tugas dengan baik sehingga akan meningkatkan kinerja pegawai. Pegawai yang berada dalam lingkungan kerja yang nyaman akan mampu meningkatkan kepuasan dalam bekerja sehingga pegawai tersebut akan berkomitmen terhadap organisasinya (Akhtar, 2014). Beberapa penelitian mengenai pengaruh lingkungan kerja terhadap kinerja telah dilakukan dan hasilnya beragam. Penelitian yang dilakukan oleh Manaf et al. (2015), dan Muda et al. (2015) menyatakan bahwa lingkungan kerja berpengaruh terhadap kinerja. Penelitian oleh Arianto (2013) menyatakan bahwa lingkungan kerja tidak berpengaruh terhadap kinerja.

Berdasarkan hasil yang tidak konsisten dari penelitian terdahulu mendorong peneliti meneliti kembali dengan mengangkat judul tentang Pengaruh Budaya Organisasi, Lingkungan Kerja dan Kompensasi pada Kinerja Karyawan di Koperasi Pasar Srinadi Klungkung. Penelitian ini meneliti kinerja 
bagian akuntansi dan keuangan karena bagian ini tidak berhubungan secara langsung dengan operasi yang menghasilkan pendapatan. Bagian akuntansi dan bagian keuangan lebih bersifat administrasi sehingga kinerjanya sering tidak terukur atau tidak nampak dimata pimpinan. Atas dasar fenomena ini peneliti ingin menguji secara empiris kinerja karyawan khususnya dibagian akuntansi dan keuangan.

Berkaitan dengan permasalahan yang telah dirumuskan, maka tujuan penelitian ini untuk memperoleh bukti empiris tentang pengaruh budaya organisasi pada kinerja karyawan, memperoleh bukti empiris tentang pengaruh lingkungan kerja pada kinerja karyawan, dan bukti empiris tentang pengaruh kompensasi pada kinerja karyawan Koperasi Pasar Srinadi Klungkung. Penelitian ini dapat dijadikan sebagai bahan pertimbangan bagi Koperasi Pasar Srinadi Klungkung di dalam mengambil suatu kebijakan mengenai mekanisme pengelolaan anggaran dalam meningkatkan kinerja karyawan dan meningkatkan akuntabilitas koperasi dengan membangun pengukuran kinerja yang lebih baik.

Teori stewardship didefinisikan sebagai situasi di mana para manajer tidak termotivasi oleh tujuan-tujuan individu, namun lebih ditujukan pada sasaran hasil utama mereka untuk kepentingan organisasi. Menurut Chin (1998) dalam Usamah (2009), stewardship theory dibangun atas asumsi filosofis mengenai sifat manusia yakni bahwa manusia pada hakekatnya dapat dipercaya, mampu bertindak dengan penuh tanggung jawab, memiliki integritas dan kejujuran terhadap pihak lain. Inilah yang tersirat dalam hubungan fidusia (hubungan berlandaskan kepercayaan) yang dikehendaki para stakeholder. Konsep inti dari teori stewardship adalah kepercayaan. Dalam teori stewardship, manajemen sebagai pihak yang dapat dipercaya untuk bertindak dengan sebaik-baiknya bagi kepentingan publik pada umumnya maupun shareholders pada khususnya (Puspitarini, 2012).

Mangkunegara (2005:9) menyatakan bahwa kinerja karyawan merupakan hasil kerja seorang karyawan baik secara kualitas maupun kuantitas yang berhasil dicapainya dalam melaksanakan tugas sesuai dengan peran dan tanggung jawab yang diberikan kepadanya.

Istilah kinerja sering digunakan untuk menyebut prestasi atau tingkat keberhasilan individu maupun kelompok individu. Bias kinerja diketahui jika individu atau kelompok individu tersebut mempunyai kriteria keberhasilan yang telah ditetapkan. Robbins \& Judge (2013:512) mengartikan budaya organisasi sebagai sebuah sistem makna bersama yang dianut oleh para anggota yang membedakan organisasi tersebut dengan organisasi lainnya. Budaya organisasi mewakili sebuah persepsi yang sama dari para anggota organisasi. Oleh karena itu, diharapkan bahwa individu-individu yang memiliki latar belakang berbeda atau berada pada tingkatan yang tidak sama dalam organisasi dapat memahami budaya organisasi dengan pengertian yang serupa.

Robbins \& Judge (2013:512) menyatakan bahwa ada tujuh karakteristik utama yang dapat menilai budaya organisasi, yaitu:Innovation and risk taking, attention to detail, outcome orientation, people orientation, team orientation, aggressiveness, stability

Menurut Nitisemito (2002), lingkungan kerja adalah segala sesuatu yang ada di sekitar pekerja dan yang dapat mempengaruhi dalam menjalankan tugas- 
tugas yang dibebankan misalnya kebersihan, keamanan, musik dan sebagainya. Dalam menciptakan lingkungan kerja agar dapat menunjang aktifitas organisasi maka diperlukan pengaturan lingkungan kerja seperti udara, cahaya dan warna.

Lingkungan kerja merupakan salah satu faktor penting dalam menciptakan kinerja pegawai. Lingkungan kerja mempunyai pengaruh langsung terhadap pegawai dalam menyelesaikan pekerjaan yang pada akhirnya akan meningkatkan kinerja organisasi. Suatu kondisi lingkungan kerja dikatakan baik apabila karyawan dapat melaksanakan kegiatan secara optimal, aman, dan nyaman.

Menurut Mahmudi (2010:173), manajemen kompensasi merupakan mekanisme penting untuk mendorong dan mempengaruhi karyawan dalam organisasi untuk mencapai tujuan organisasi. Sistem kompensasi merupakan salah satu alat untuk mempengaruhi motivasi karyawan dalam organisasi. Sistem kompensasi yang adil dan mensejahterakan akan dapat memacu semangat kerja dan memperbaiki moralitas pegawai. Sebaliknya, sistem kompensasi yang tidak adil, diskriminatif dan tidak mampu mensejahterakan pegawai akan memicu rendahnya motivasi, semangat kerja, dan moralitas pegawai.

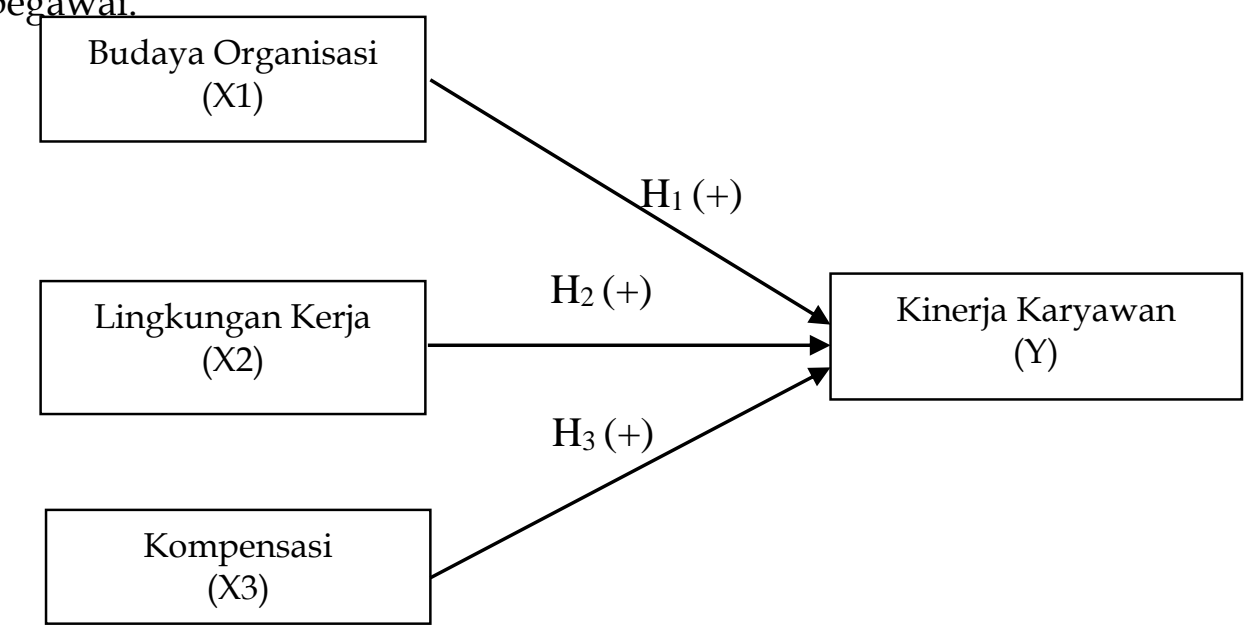

Sumber: Data Penelitian, 2018

\section{Gambar 1. Kerangka Konseptual}

Berdasarkan stewardship theory, organisasi harus mampu memfasilitasi tumbuhnya budaya organisasi terkait dengan kinerja karyawan dan memahami pentingnya sumber daya yang dimiliki bisa dikelola untuk dapat mengelola kinerja. Budaya organisasi merupakan implementasi dari attitude atau sikap yang menjadi perpaduan antara nilai-nilai yang ditanamkan organisasi dalam rangka mencapai tujuan organisasi. Budaya organisasi yang dibina dengan baik akan mempengaruhi perilaku karyawan yang akan berdampak pada prestasi kerja karyawan. Kumpulan prestasi kerja individu setiap karyawan pada akhirnya akan tercermin pada kinerja karyawan secara keseluruhan. Pernyataan tersebut sejalan dengan penelitian yang dilakukan oleh Heriyanti (2007), Chasanah (2008), Evawati \& Suharno (2015) serta Ponnu \& Hassan (2015) yang mengemukakan bahwa ada hubungan antara budaya organisasi dan kinerja yaitu ada korelasi signifikan positif antara budaya organisasi dan kinerja. 
Berdasarkan stewardship theory dan penelitian-penelitian terdahulu dapat disimpulkan bahwa budaya organisasi yang terbina dengan baik dalam organisasi akan mempengaruhi perilaku karyawan yang selanjutnya akan bermuara pada prestasi kerja karyawan. Dalam organisasi, implementasi budaya dirupakan dalam bentuk perilaku, artinya perilaku individu dalam organisasi akan diwarnai oleh budaya organisasi yang bersangkutan. Perilaku karyawan yang sesuai dengan budaya organisasi tersebut akan memberikan efek pada meningkatnya kinerja karyawan, karena budaya organisasi ditetapkan oleh manajemen demi mewujudkan visi dan misi organisasi yang salah satunya adalah meningkatkan kualitas dan daya saing sumber daya manusia. Berdasarkan penjelasan tersebut, dapat dirumuskan hipotesis sebagai berikut.

$\mathrm{H}_{1} \quad$ : Budaya organisasi berpengaruh positif pada kinerja karyawan Koperasi Pasar Srinadi Klungkung

Berdasarkan stewardship theory, dalam lingkungan bisnis yang kompetitif, organisasi harus mampu memanfaatkan potensi tenaga kerja karyawannya. Faktor kunci yang harus diperhatikan adalah lingkungan kerja karyawan sangat berdampak pada tingkat motivasi dan kinerja. Karyawan akan termotivasi untuk meningkatkan produktivitas atau kinerja apabila lingkungan kerja mendukung pelaksanaan tugas dan kewajibannya. Kinerja dapat meningkat apabila didukung oleh lingkungan kerja yang memadai. Lingkungan kerja haruslah sesuai dengan kebutuhan dari karyawan agar dapat lebih maksimal dalam menyelesaikan tugasnya.

Gambaran atas fenomena tersebut selaras dengan penelitian yang telah dilakukan oleh Evawati \& Suharno (2015), Muda, et al (2015), dan Manaf, et al (2015) yang meneliti pengaruh lingkungan kerja terhadap kinerja pegawai. Hasil penelitian ini menunjukkan bahwa lingkungan kerja berpengaruh signifikan terhadap kinerja pegawai. Berdasarkan stewardship theory dan penelitianpenelitian terdahulu dapat disimpulkan bahwa lingkungan kerja merupakan salah satu faktor yang mempengaruhi kinerja karyawan. Seorang karyawan yang bekerja di lingkungan yang mendukung untuk bekerja secara optimal akan menghasilkan kinerja yang baik, sebaliknya jika seorang karyawan bekerja dalam lingkungan kerja yang tidak memadai dan tidak mendukung untuk bekerja secara optimal akan membuat karyawan yang bersangkutan menjadi malas, cepat lelah sehingga kinerja karyawan tersebut akan rendah. Berdasarkan penjelasan tersebut, dapat dirumuskan hipotesis sebagai berikut.

$\mathrm{H}_{2} \quad$ : Lingkungan kerja berpengaruh positif pada kinerja karyawan Koperasi Pasar Srinadi Klungkung

Berdasarkan stewardship theory, pemberian kompensasi memiliki arti penting bagi organisasi dan karyawan yaitu sebagai salah satu upaya untuk memotivasi karyawan agar dapat menghasilkan kinerja yang optimal sehingga dapat menunjang pencapaian tujuan dan kesuksesan oragnisasi. Penelitian sebelumnya yang meneliti pengaruh kompensasi pada kinerja yaitu Hameed, Ramzan, Zubair, Ali, \& Arslan (2014), Nurcahyani \& Adnyani (2016), dan Muhammad \& Abdullah (2016). Hasil penelitian-penelitian tersebut menunjukkan bahwa kompensasi memiliki pengaruh positif yang signifikan terhadap kinerja organisasi. 
Berdasarkan stewardship theory dan penelitian-penelitian terdahulu menggambarkan bahwa kompensasi dapat meningkatkan prestasi kerja karyawan. Oleh karena itu, pemberian kompensasi secara rasional dan adil sangat diperlukan. Namun realitas menunjukkan bahwa dilapangan terdapat kelompok karyawan yang berkontribusi langsung dengan upaya perusahaan menghasilkan pendapatan, dan kelompok karyawan yang tidak memiliki kontribusi langsung pada upaya perusahaan dalam menghasilkan pendapatan yaitu bagian akuntansi dan keuangan atau yang sering disebut dengan bagian administrasi. Bila karyawan memandang pemberian kompensasi tidak memadai, maka kinerja mereka akan cenderung menurun. Berdasarkan penjelasan tersebut, dapat dirumuskan hipotesis sebagai berikut.

$\mathrm{H}_{3} \quad$ : Kompensasi berpengaruh positif pada kinerja karyawan Koperasi Pasar Srinadi Klungkung

\section{METODE PENELITIAN}

Lokasi penelitian ini dilakukan di unit usaha di Koperasi Pasar Srinadi Klungkung, Kabupaten Klungkung. Subjek dalam penelitian ini adalah karyawan bagian akuntansi dan keuangan pada masing-masing unit usaha di Koperasi Pasar Srinadi Klungkung, Kabupaten Klungkung.Obyek penelitian ini adalah Pengaruh Budaya Organisasi, Lingkungan Kerja, Kompensasi pada Kinerja Karyawan Bagian Akuntansi dan Keuangan di Koperasi Pasar Srinadi Klungkung.

Variabel Independen (bebas), yaitu variabel yang menjelaskan dan mempengaruhi variabel lain. Adapun yang menjadi variabel independen dalam penelitian ini adalah Budaya Organisasi $\left(X_{1}\right)$, Lingkungan Kerja $\left(X_{2}\right)$, dan Kompensasi $\left(X_{3}\right)$. Variabel Dependen (terikat), yaitu variabel yang dijelaskan dan dipengaruhi oleh variabel independen.Variabel terikat dalam penelitian ini adalah Kinerja Karyawan (Y). Populasi yang digunakan dalam penelitian ini adalah karyawan Koperasi Pasar Srinadi Klungkung, yang berjumlah 304 orang. Sampel yang digunakan adalah seluruh karyawan bagian akuntansi dan keuangan pada seluruh unit usaha di Koperasi Pasar Srinadi Klungkung.

Metode penentuan sampel yang digunakan dalam penelitian ini adalah metode non probability sampling dengan teknik purposive sampling. Kriteria tersebut adalah seluruh karyawan bagian akuntansi dan keuangan pada seluruh unit usaha di Koperasi Pasar Srinadi Klungkung. Karyawan tersebut berjumlah 50 orang meliputi karyawan bagian akuntansi dan bagian keuangan seperti kasir.

Metode pengumpulan data yang digunakan dalam penelitian ini kuesioner tertutup yaitu setiap pertanyaan telah disertai sejumlah pilihan jawaban yang kemudian responden hanya memilih yang paling sesuai. Skala alternatif jawaban yang digunakan adalah skala likert, yaitu skala yang digunakan untuk mengukur sikap, pendapat, dan persepsi seseorang tentang fenomena sosial tertentu (Sugiyono, 2017). Penggunaan instrumen kuesioner yang menggunakan skala likert dengan empat skala memiliki kelebihan dapat menjaring data penelitian lebih akurat dikarenakan kategori jawaban undeciden yang mempunyai artiganda, atau bisa diartikan responden belum dapat memutuskan atau memberi jawaban, tidak digunakan di dalam kuesioner dikarenakan dapat menimbulkan (central tendency effect) yang dapat 
menghilangkan banyak data penelitian sehingga mengurangi banyaknya informasi yang dapat dijaring dari para responden.

Penelitian ini hanya menggunakan data kuantitatif. Data kuantitatif diperoleh dari data kualitatif yang diangkakan (scoring). Scoring yang digunakan dalam penelitian ini dari 1 sampai 4 . Sumber data yang digunakan dalam penelitian ini adalah data primer dan data sekunder. Data primer adalah data yang diperoleh peneliti secara langsung dengan cara menyebar angket kuesioner yang terdapat beberapa pertanyaan yang dibuat oleh peneliti dan akan diserahkan kepada responden. Sedangkan data sekunder adalah data yang diperoleh peneliti dari sumber yang sudah ada.

Persamaan regresi linier berganda ingin menguji pengaruh dua atau lebih variabel independen terhadap suatu variabel dependen dan umumnya dinyatakan dalam persamaan sebagai berikut.

$Y=a+\beta_{1} X_{1}+\beta_{2} X_{2}+\beta_{3} X_{3}+\varepsilon$

Keterangan:

$\mathrm{Y} \quad=$ Kinerja Karyawan

a $\quad=$ Nilai intercept $/$ constant

$\mathrm{X} 1 \quad=$ Variabel Budaya Organisasi

X2 $\quad=$ Variabel Lingkungan Kerja

$\mathrm{X} 3 \quad=$ Variabel Kompensasi

$\beta 1, \beta 2, \beta 3=$ Koefisien regresi variabel bebas

$\mathcal{E} \quad=$ Standar error (tingkat kesalahan)

Pengujian asumsi klasik digunakan untuk mengetahui kondisi data yang ada agar dapat menentukan model analisis yang tepat. Data yang digunakan sebagai model regresi berganda dalam menguji hipotesis haruslah menghindari kemungkinan terjadinya penyimpangan asumsi klasik.

\section{HASIL DAN PEMBAHASAN}

Penelitian ini dilakukan untuk mengetahui pengaruh budaya organisasi, lingkungan kerja dan kompensasi pada kinerja karyawan. Data dikumpulkan dengan menyebarkan kuesioner ke sembilan unit usaha yang ada di Koperasi Pasar Srinadi Klungkung. Jumlah kuesioner yang disebar pada penelitian ini sebanyak 50 eksemplar, yang dikhususkan kepada karyawan bagian akuntansi dan keuangan. Setiap unit terdapat satu karyawan bagian akuntansi sehingga ada sembilan karyawan bagian akuntansi untuk seluruh unit. Karyawan bagian keuangan berjumlah 41 orang karyawan yang tersebar di seluruh unit.

Berdasarkan hasil uji validitas dapat disimpulkan bahwa instrumen penelitian yang terdiri dari item-item pernyataan budaya organisasi $\left(X_{1}\right)$, lingkungan kerja $\left(\mathrm{X}_{2}\right)$, kompensasi $\left(\mathrm{X}_{3}\right)$, kinerja karyawan $(\mathrm{Y})$ adalah valid. Hal ini dikarenakan korelasi antara skor masing - masing pernyataan dengan skor total besarnya lebih dari 0,30 .

Berdasarkan hasil uji reliabilitas dapat disimpulkan bahwa variabelvariabel yang digunakan dalam penelitian ini adalah reliabel karena keseluruhan variabel memiliki Cronbach's Alpa yang lebih besar dari 0,7 sehingga layak digunakan menjadi alat ukur instrumen kuesioner dalam penelitian ini. 
Hasil uji normalitas menunjukkan bahwa nilai signifikansi dari hasil uji normalitas pada persamaan tersebut sebesar 0,200. Hal tersebut menunjukkan bahwa data berdistribusi normal karena nilai Asymp. Sig lebih besar dari 0,05.

Berdasarkan hasil Uji Multikolinearitas menunjukkan variabel bebas dalam model regresi tidak saling berkorelasi. Diperoleh nilai tolerance dari masingmasing variabel lebih besar dari 0,10 dan nilai VIF diperoleh lebih kecil dari 10. Hal tersebut menunjukkan tidak adanya korelasi antara sesama variabel bebas dalam model regresi, sehingga dapat disimpulkan bahwa tidak terdapat masalah multikolinearitas.

Model regresi yang baik adalah yang homoskedastisitas atau tidak terjadi heteroskedastisitas. Deteksi kasus heteroskedastisitas dapat dilakukan dengan uji Glejser dengan melihat tingkat signifikansi berada lebih dari 0,05. Berdasarkan hasil uji heterokedastisitas dapat dilihat bahwa nilai signifikansi masing-masing variabel pada model regresi nilainya lebih besar dari 0,05. Hal tersebut menunjukkan bahwa model regresi tersebut tidak megandung heteroskedastisitas.

Tabel 1. Hasil Analisis Regresi Linear Berganda

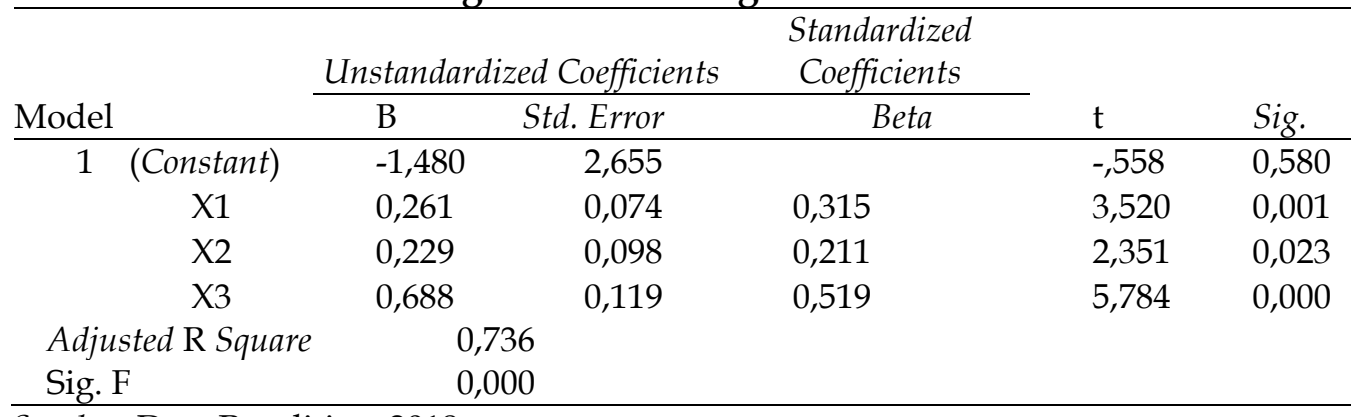

Sumber: Data Penelitian, 2018

Analisis regresi ini digunakan untuk melihat pengaruh variabel $X$ terhadap variabel Y. Berdasarkan Tabel 1, dapat diringkas model persamaan regresi linear bergandanya sebagai berikut.

$$
\mathrm{Y}=-1480+0,261 \mathrm{X}_{1}+0,229 \mathrm{X}_{2}+0,688 \mathrm{X}_{3}+\varepsilon
$$

Berdasarkan Tabel 1, beberapa hal yang dapat diketahui yaitu: Nilai koefisien beta dari variabel budaya organisasi bernilai positif yang berarti bahwa semakin tinggi budaya organisasi, menyebabkan semakin meningkat kinerja karyawan. Nilai koefisien beta dari variabel lingkungan kerja bernilai positif yang berarti bahwa semakin tinggi lingkungan kerja, menyebabkan semakin meningkatnya kinerja karyawan. Nilai koefisien beta dari variabel kompensasi bernilai positif yang berarti bahwa semakin tinggi kompensasi, menyebabkan kinerja karyawan semakin meningkat.

Nilai konstanta sebesar -1,480 menunjukkan bahwa variabel budaya organisasi, lingkungan kerja, kompensasi sama dengan nol (tetap atau tidak berubah), menyebabkan kinerja karyawan akan menurun sebesar konstantanya. Variabel kompensasi memiliki nilai koefisien beta standardized yang paling tinggi yaitu 0,519 , sedangkan variabel budaya organisasi sebesar 0,315 dan yang paling kecil adalah lignkungan kerja sebesar 0,211. Hal tersebut menunjukan bahwa variabel kompensasi adalah variabel yang berpengaruh dominan terhadap kinerja karyawan. 
Hasil analisis menunjukkan nilai Adjusted Rsquare sebesar 0,736. Hal ini berarti perubahan yang terjadi pada kinerja karyawan dapat dijelaskan oleh budaya organisasi, lingkungan kerja, dan kompensasi sebesar 73,6 persen, sedangkan sisanya 26,4 persen dijelaskan oleh faktor lain yang tidak diuji dalam penelitian ini. Berdasarkan Tabel 1, nilai signifikansi F atau p-value sebesar 0,000 yang lebih kecil dari nilai $a=0,05$. Ini menunjukkan bahwa regresi ini layak digunakan sebagai alat analisis untuk menguji pengaruh variabel bebas pada variabel terikat.

Uji statistik $\mathrm{t}$ dilakukan dengan membandingkan hasil nilai siginifikansi 0,05. Nilai koefisien regresi untuk variabel budaya organisasi berdasarkan Tabel 1, sebesar 0,261 dengan tingkat signifikansi sebesar 0,001 $<0,05$, maka $\mathrm{H}_{1}$ diterima. Hal ini mengindikasikan bahwa budaya organisasi berpengaruh positif dan siginifikansi pada kinerja karyawan.

Nilai koefisien regresi untuk variabel lingkungan kerja berdasarkan Tabel 1, sebesar 0,229 dengan tingkat signifikansi sebesar 0,023 $<0,05$, maka $\mathrm{H}_{2}$ diterima. Hal ini mengindikasikan bahwa lingkungan kerja berpengaruh positif dan siginifikansi pada kinerja karyawan. Nilai koefisien regresi untuk variabel kompensasi berdasarkan Tabel 1, sebesar 0,688 dengan tingkat signifikansi sebesar $0,000<0,05$, maka $\mathrm{H}_{3}$ diterima. Hal ini mengindikasikan bahwa kompensasi berpengaruh positif dan siginifikansi pada kinerja karyawan.

Berdasarkan hasil pengujian menunjukkan variabel budaya organisasi berpengaruh positif dan signifikan pada kinerja karyawan, berarti hipotesis pertama $\left(\mathrm{H}_{1}\right)$ diterima. Hasil ini menunjukkan bahwa meningkatnya budaya organisasi meningkatkan kinerja karyawan. Budaya organisasi yang diterapkan oleh Koppas Srinadi Klungkung dapat dilihat dari perilaku hubungan, perilaku tugas dan kematangan bawahan yang diterapkan selama mengelola koperasi. Keberhasilan penerapan budaya organisasi ini dapat dilihat dari jawaban responden yang rata-rata memberikan penilaian positif terhadap pernyataanpernyataan yang mencerminkan indikator pengukuran dari variabel budaya organisasi, meliputi karakter organisasi, gaya kepemimpinan, ikatan dengan organisasi, dan penekanan strategis. Berdasarkan hasil olahan data kuesioner dapat dibuktikan bahwa budaya organisasi telah diterapkan di Koperasi Pasar Srinadi Klungkung, sehingga kinerja karyawan semakin meningkat

Hasil penelitian ini didukung oleh penelitian yang dilakukan Heriyanti (2007), Chasanah (2008), Evawati \& Suharno (2015) serta Ponnu \& Hassan (2015) yang mengemukakan bahwa ada hubungan antara budaya organisasi dan kinerja yaitu ada korelasi signifikan positif antara budaya organisasi dan kinerja.

Hasil pengujian menunjukkan variabel lingkungan kerja berpengaruh positif dan signifikan pada kinerja karyawan, berarti hipotesis kedua $\left(\mathrm{H}_{2}\right)$ diterima. Hal tersebut mengindikasikan bahwa semakin tinggi lingkungan kerja maka kinerja karyawan akan semakin tinggi. Hasil tersebut konsisten dengan jawaban responden, dimana sebagian besar responden memberikan tanggapan positif terhadap setiap pernyataan yang menunjukkan indikator pengukuran lingkungan kerja. Hal ini menunjukkan bahwa lingkungan kerja di Koppas Srinadi mampu mempengaruhi kinerja karyawan.

Hasil Penelitian ini didukung oleh penelitian yang dilakukan Evawati \& Suharno (2015), Muda et al. (2015), dan Manaf et al. (2015) yang meneliti 
pengaruh lingkungan kerja terhadap kinerja pegawai. Hasil penelitian ini menunjukkan bahwa lingkungan kerja berpengaruh signifikan terhadap kinerja pegawai. Berdasarkan stewardship theory dan penelitian-penelitian terdahulu dapat disimpulkan bahwa lingkungan kerja merupakan salah satu faktor yang mempengaruhi kinerja karyawan.

Hasil pengujian menunjukkan variabel kompensasi berpengaruh positif dan signifikan pada kinerja karyawan, berarti hipotesis ketiga $\left(\mathrm{H}_{3}\right)$ diterima. Hubungan positif yang diperoleh dari hasil pengujian mengindikasikan bahwa dengan diberikannya kompensasi maka kinerja karyawan akan semakin meningkat. Hasil tersebut konsisten dengan jawaban responden, dimana sebagian besar responden memberikan tanggapan positif terhadap setiap pernyataan yang menunjukkan indikator pengukuran variabel kompensasi. Ini berarti Koppas Srinadi Klungkung telah memberikan kompensasi yang mampu meningkatkan kinerja karyawan, sehingga kemampuan teknis karyawan dalam menjalankan tugas akan semakin membaik.

Penelitian sebelumnya yang meneliti pengaruh kompensasi pada kinerja yaitu Hameed et al. (2014), Nurcahyani \& Adnyani (2016), dan Muhammad \& Abdullah (2016). Hasil penelitian-penelitian tersebut menunjukkan bahwa kompensasi memiliki pengaruh positif yang signifikan terhadap kinerja organisasi.

Hasil penelitian ini dapat memberikan tambahan informasi dalam kajian empiris mengenai budaya organisasi, lingkungan kerja, dan kompensasi pada kinerja kayawan. Terdapat bukti empiris yang diperoleh melalui penelitian ini, menunjukkan bahwa adanya pengaruh positif dan signifikan dari budaya organisasi, lingkungan kerja, dan kompensasi pada kinerja karyawan. Hal tersebut juga didukung oleh teori stewardship yang menyatakan bahwa situasi di mana para manajer tidak termotivasi oleh tujuan-tujuan individu, namun lebih ditujukan pada sasaran hasil utama mereka untuk kepentingan organisasi. Teori ini berdasar pada pertimbangan-pertimbangan yang terkait dengan motivasi manajer. Stewardship theory dibangun atas dasar asumsi psikologi dan sosiologi yang telah dirancang dimana para eksekutif sebagai steward didorong untuk bertindak sesuai keinginan terbaik prinsipal mereka, selain itu perilaku steward tidak akan terlepas dari kepentingan organisasinya. Penelitian ini juga dapat dijadikan referensi konseptual serta perbandingan pengembangan dan penyempurnaan dari penelitian terdahulu.

Hasil penelitian ini dapat memberikan masukan bagi sebuah koperasi mengenai pengaruh dari budaya organisasi, lingkungan kerja, dan kompensasi pada kinerja karyawan, sehingga kinerja sebuah koperasi akan semakin meningkat, baik dari segi kualitas maupun kuantitas dan target koperasi akan mudah tercapai.

\section{SIMPULAN}

Berdasarkan hasil analisis yang diperoleh dalam penelitian ini, maka dapat disimpulkan sebagai berikut. Budaya organisasi berpengaruh positif dan signifikan pada kinerja karyawan. Hal ini bermakna bahwa semakin baik budaya organisasi yang dimiliki maka menyebabkan peningkatan terhadap kinerja karyawan. Lingkungan kerja berpengaruh positif dan signifikan pada kinerja 
karyawan. Hal ini bermakna bahwa semakin baik lingkungan kerja maka akan berdampak terhadap meningkatnya kinerja karyawan tersebut. Kompensasi berpengaruh positif dan signifikan pada kinerja karyawan. Hal ini bermakna bahwa pemberian kompensasi mampu meningkatkan kinerja karyawan.

Berdasarkan simpulan, saran yang peneliti berikan adalah sebagai berikut. Manajer Koperasi Pasar Srinadi Klungkung harus memperhatikan pemberian kompensasi dan perhatian terhadap lingkungan kerja secara menyeluruh sehingga akan terjadi kenyamanan dalam proses kerja di dalam koperasi. Seluruh karyawan Koperasi Pasar Srinadi Klungkung harus secara serentak meningkatkan budaya organisasi yang baik, sehingga kinerja karyawan akan semakin membaik. Seluruh karyawan Koperasi Pasar Srinadi Klungkung juga diharapkan lebih mengedepankan cara-cara baru dalam memecahkan permasalahan yang ada di koperasi.

\section{REFERENSI}

Akhtar, J. (2014). Impact Of Work Environment, Salary Package And Employees ' Perception On Organizational Commitment: A Study Of Small \& Medium Enterprises ( SMEs ) Of Pakistan. International Journal of Academic Research in Business and Social Sciences, 4(8), 147-165. https://doi.org/10.6007/IJARBSS/v4-i8/1081

Alwi, Syafaruddin. (2001). Manajemen Sumber Daya Manusia, Strategi Keunggulan Kompetitif. BPFE UGM, Yogyakarta.

Arianto, D. A. N. (2013). Pengaruh Kedisiplinan, Lingkungan Kerja dan Budaya Kerja Terhadap Kinerja Tenaga Pengajar. Jurnal Economia, 9(2), 191-200.

Chasanah, N. (2008). Analisis Pengaruh Empowerment, Self Efficacy Dan Budaya Organisasi Terhadap Kepuasan Kerja Dalam Meningkatkan Kinerja Karyawan (Studi Empiris pada Karyawan PT. Mayora Tbk Regional Jateng dan DIY). Universitas Diponegoro.

Chin, W. . (1998). The Partial Least Squares Approach to Structural Equation Modeling in G.A. Marcoulides (Ed.). Modern Methods for Business Research, 295-336.

Davis, J. H., Schoorman, F. D., \& Donaldson, L. (1997). Toward A Stewardship Theory of Management. The Academy of Management Review, 22(1), 20-47. https://doi.org/10.5465/ AMR.1997.9707180258

Djatnika Sri, S. Ariffin, Jochen Ropke. (2003). Ekonomi Koperasi, Teori dan manajemen. Salemba Empat: Jakarta

Evawati, \& Suharno. (2015). The Effect Of Organization Culture And Working Environment On Employee Performance At PT. Asuransi Jiwa Sequislife Jakarta. European Journal of Business and Management, 7(6), 205-218.

Hameed, A., Ramzan, M., Zubair, H. M. K., Ali, G., \& Arslan, M. (2014). Impact of Compensation on Employee Performance (Empirical Evidence from Banking Sector of Pakistan ). International Journal of Business and Social Science, 5(2), 302-309.

Heriyanti, D. (2007). Analisis Pengaruh Budaya Organisasi, Kepuasan Kerja, Dan Gaya Kepemimpinan Terhadap Kinerja Karyawan Dengan Komitmen Organisasional Sebagai Variabel Intervening (Studi PT. PLN (Persero) APJ Semarang). Universitas Diponegoro. \ 
Idris, M. (2015). The impact of organisational commitment, motivation and financial compensation on work satisfaction and employees' performance: An evidence from small business firms in South Sumatera-Indonesia. International Journal of Applied Business and Economic Research, 13(4), 1549-1562.

Kanaidi. (2015). Koperasi dan UMKM: Tantangan dalam Menumbuhkan Jiwa Kewirausahaan. Jakarta: Kencana

Kabar24.bisnis.com. (2017). Ada 10\% Koperasi Tidak Aktif di Bali. (online). (http:/ / kabar24.bisnis.com/read/20180105/78/723666/ada-10-kop, diakses tanggal 10 Juli 2018)

Mahmudi. (2010). Manajemen Kinerja Sektor Publik (Edisi Kedua). Yogyakarta: Sekolah Tinggi Ilmu Manajemen YKPN.

Manaf, I. G., Lubis, A. R., \& Ibrahim, M. (2015). Pengaruh Lingkungan Kerja dan Disiplin terhadap Motivasi Kerja Pegawai dan Implikasinya terhadap Kinerja Sekretariat Kecamatan dalam Kabupaten Simeulue. Jurnal Manajemen Pascasarjana Universitas Syiah Kuala, 4(1), 79-88.

Mangkunegara, A. P. (2005). Perilaku dan Budaya Organisasi. Bandung: Refika Aditama.

Muda, T. I., Yunus, M., \& Amri. (2015). Pengaruh Lingkungan Kerja, Kompensasi dan Motivasi terhadap Kinerja Karyawan dan Implikasinya terhadap Kinerja Pt. Pln (persero) Wilayah Aceh. Jurnal Manajemen Pascasarjana Universitas Syiah Kuala, 4(1), 89-97.

Muhammad, I. G., \& Abdullah, H. H. (2016). Assessment of Organizational Performance: Linking the Motivational Antecedents of Empowerment, Compensation and Organizational Commitment. International Review of Management and Marketing, 6(4), 974-983.

Murty, W. A., \& Hudiwinarsih, G. (2012). Pengaruh Kompensasi, Motivasi dan Komitmen Organisasional terhadap Kinerja Karyawan Bagian akuntansi (studi kasus pada perusahaan manufaktur di surabaya). The Indonesian Accounting Review, 2(2), 215-228.

Nurcahyani, N. M., \& Adnyani, I. G. . D. (2016). Pengaruh Kompensasi Dan Motivasi Terhadap Kinerja Karyawan Dengan Kepuasan Kerja Sebagai Variabel Intervening. E-Jurnal Manajemen Unud, 5(1), 500-532.

Olson, J. D., \& Borman, C. . (1989). More Evidence on Relationships Between The Work Environment and Job Performance. Human Performance, 2(2), 113130.

Oparanma, A. O. (2010). The Organizational Culture And Corporate Performance In Nigeria. International Journal of African Studies, 3(3), 34-40.

Peraturan Menteri Koperasi Dan Usaha Kecil Dan Menengah Nomor 20 Tahun 2015 Tentang Penerapan Akuntabilitas Koperasi.

Ponnu, A. L. D., \& Hassan, Z. (2015). The Influences of Organizational Culture on Performance Management. International Journal of Accounting, Business and Management (IJABM), 3(1), 135-145.

Puspitarini, N. D. (2012). Peran Satuan Pengendalian Internal dalam Pencapaian Good University pada Perguruan Tinggi Berstatus PK-BLU. Accounting Analysis Journal, 1(2), 1-8.

Rediyono, \& Ujianto. (2013). Pengaruh Inovasi, Budaya Organisasi dan 
Teamwork Terhadap Kinerja Manajerial Serta Implikasinya Pada Kinerja Bank Perkreditan Rakyat di Provinsi Kalimantan Timur. Jurnal Ilmu Ekonomi \& Manajemen, 9(2), 103-119.

Retnaningsih, S. (2007). Analisis Pengaruh Keadilan Kompensasi, Peran Kepemimpinan, dan Kepuasan Kerja terhadap Komitmen Organisasi dalam Meningkatkan Kinerja Karyawan (Studi Kasus: Pada Sentral Pengolahan Pos Semarang). Universitas Diponegoro.

Robbins, S. P., \& Judge, T. A. (2013). Organizational Behavior (Fifteenth). Prentice Hall.

Sedarmayanti. (2001). Sumber Daya Manusia dan Produktivitas Kerja. Bandung: Mandar Maju.

Sitio, Arifin. (2011). Koperasi : Teori dan Praktik. Jakarta : Erlangga

Sugiyono. (2017). Metode Penelitian Kuantitatif, Kualitatif, dan Kombinasi (Mixed Methods). Bandung: Alfabeta

Supianto, Y. (2015). Pengaruh Kompensasi, Kompetensi dan Komitmen Organisasional Terhadap Kepuasan dan Kinerja. Jurnal Economia, 11, 118131.

Suryadi Limbunan dan Josua Tarigan. (2016). Budaya Organisasi terhadap Kinerja Keuangan dengan Menggunakan Perilaku Pemilik atas Isu Manajemen Lingkungan sebagai Variabel Intervening. Business Accounting Review, 4 (1), 157-168.

Syauta, J. H., Troena, E. A., Setiawan, M., \& Solimun. (2012). The Influence of Organizational Culture, Organizational Commitment to Job Satisfaction and Employee Performance (Study at Municipal Waterworks of Jayapura , Papua Indonesia ). International Journal of Business and Management Invention, 1(1), 69-76.

Trisnaningsih, S. (2007). Independensi Auditor dan Komitmen Organisasi sebagai Mediasi Pengaruh Pemahaman Good Governance, Gaya Kepemimpinan dan Budaya Organisasi terhadap Kinerja Auditor. Simposium Nasional Akuntansi X, 1-56.

Tseng, S. (2010). The Correlation Between Organizational Culture And Knowledge Conversion On Corporate Performance. Journal of Knowledge Management, 14(2), 269-284.

Undang - Undang Republik Indonesia Nomor 25 Tahun 1992 tentang Perkoperasian.

Usamah. (2009). Peran Kompetensi dan Model Pengorganisasian Dewan Pengawas Syariah terhadap Pembiayaan Berbasis Bagi Hasil pada Perbankan Syariah di Indonesia. Universitas Diponegoro.

Usmany, T. P., Hamid, D., \& Utami, H. N. (2016). Pengaruh Budaya Organisasi terhadap Komitmen Organisasional dan Kinerja Karyawan (Studi pada Karyawan Pabrik Gondorukem dan Terpentin Sukun Perum Perhutani Kesatuan Bisnis Mandiri Industri Gondorukem dan Terpentin II, Ponorogo). Jurnal Administrasi Bisnis (JAB), 37(2), 38-44.

Vertasari, O., \& Zunaidah. (2014). Pengaruh Kompensasi, Kompetensi dan Lingkungan Kerja terhadap Kinerja para Pegawai Badan Penanggulangan Bencana Provinsi Sumatera Selatan. Jurnal Manajemen Dan Bisnis Sriwijaya, 12(4), 317-330. 